Arab Univ. J. Agric. Sci., Ain Shams Univ., Cairo, 13(3), 795-805, 2005

\title{
GC-MASS ANALYSIS OF BITTER ORANGE PETITGRAIN BIGARADE OIL PRODUCED IN EGYPT AND STORED UNDER DIFFERENT TEMPERATURES
}

[52]

\author{
Abd El-Rashid ${ }^{1}$, A.
}

\begin{abstract}
Identification of bitter orange petitgrain bigarade oil produced in Egypt was studied by GC/MS on carbowax - 20M colum. It was found that linalyl acetate, which represented more than $25 \%$ of the whole oil was considered to be the major component of ester fraction; while linalool, which ranged from (30-33.7\%) was the main alcohol components. On the other hand, limonene, (E)- $\beta$-ocimene,myrcene and $\beta$-pinene were the highest monoterpene hydrocarbons. Room temperature (about $20^{\circ} \mathrm{C}$ ), 4 and $-18^{\circ} \mathrm{C}$ were used for storing the samples for 6 mounths. No pronounced effect was noticed on the composition of petitgrain oil with the exception of slight effect on the color, acid number and solubility (v/v 70\% alcohol) when samples stored at $20^{\circ} \mathrm{C}$. Statistical analyses proved that $4{ }^{\circ} \mathrm{C}$ could be considered the best fit temperature at which no significant changes occur in both the major chemical analyses and the main identified volatile constituents.
\end{abstract}

Key Words: Citrus aurantium, Petitgrain bigarade oil composition, Automated GC/MS, Linalyl acetate, Linalool.

\section{INTRODUCTION}

Citrus aurantium swingle is commonly known as the bitter, sour or Seville orange. Bitter orange is a source of several important products, although they are not usually produced from the same subspecies. The most wide spread products are classified by Boelens and Oporto, (1991).as follows: leaf oils chiefly petitgrain, flower oils mainly neroli, peel and fruit oils. Leaf oil is considered to be a secondary product from bitter orange trees grown to produce the oil and so, being in second order after flower oil. The most important constituent of leaf oil that defines its quality is it's ester content which usually calculated as linalyl acetate; and the oil is sold commercially and marketly categorized on such a base; (Boelens, 1991).

Petitgrain bigarade is produced mainly in Europe and North Africa, while

1- Food Science Department, Faculty of Agriculture, Ain Shams University, Shoubra El-Kheima, Cairo, Egypt. 
Arab Univ. J. Agric. Sci., Ain Shams Univ., Cairo, 13(3), 795-805, 2005

petitgrain from other localities is usually designated by the country of origin; i.e petitgrain Paraguay and Haiti (Lawrence, 1993).

Petitgrain bigarade oils are usually obtained by steam-distillation of leafs, twigs and small unripe fruits of true bitter orange. Such oil is pale to mid-yellow but crude oil is almost black. The odor of the same oil is pleasant being of floral-sweet and orange-like characteristics. The taste like orange and bitter-sweet, are related to the high linalyl acetate content being also considered responsible for the strong sweetness. This oil is extensively used in perfumery and flavoring to enhance the frequently harsh synthetic compounds used in some food stuffs, sweets, soft drinks and cordials. North African oils are generally conform to this quality; since most plantations were established from French material (Weiss, 1997). The chemical composition of petitgrain oils is not well defined like that of citrus peel oils. This is probably due to the main following reasons: It is difficult to identify and completely quantify components of natural complex mixture such as petitgrain oils, and the samples analyzed may have different origins (Mondello and Dugo, 1996).

The aim of this study is to take a brief knowledge of the effect of different storage temperature 20,4 and $-18 \mathrm{C}^{\circ}$ on the composition of petitgrain oil produced in Egypt, to be used as reference for quality and genuineness control. To reach such goal, storage period was planned to be for 6 months and the analyses were carried out by GC/MS, using high resolution GC columns and a mass library equipped with Linear Retention Indices , which can be used interactively with MS data for component identification.

\section{MATERIAL AND METHODS}

\section{Materials}

The bitter orange petitgrain bigarade oil was provided from the Sugar and Integrated Industries Company, Perfumes and Essences Factories, Hawamdia, Giza, Egypt. In February 2004. The oil was packed in special dark vials to prevent any undesirable effect of light.

Petitgrain oils were stored at three different temperatures as follows:

$* *$ At room temperature (about $20^{\circ} \mathrm{C}$ ).

$* *$ Under cooling condition $\left(4^{\circ} \mathrm{C}\right)$.

** Under frozen condition $\left(-18^{\circ} \mathrm{C}\right)$.

Samples were analyzed at zero time, after one, 3 and 6 months for identifying the main properties of the tested oil. And the gas chromatography mass spectrum was applied for analyzing the fresh sample (zero time) as well as those stored under the aforementioned conditions.

\section{Methods}

The main properties in terms of color, specific gravity $\left(15^{\circ} \mathrm{C}\right)$, optical rotation $\left(20^{\circ} \mathrm{C}\right)$, refractive index $\left(20^{\circ} \mathrm{C}\right)$ were determined by the methods given in the AOAC. (1995). Solubility (v/v 70\% alcohol), acid number and ester number

1- Food Science Department, Faculty of Agriculture, Ain Shams University, Shoubra El-Kheima, Cairo, Egypt. 
GC-Mass analysis of bitter orange petitgrain bigarade oil

were determined by the methods described in FCC. (1996).

GC/MS analysis, was performed using HP5890 Gas Chromatograph with a flame ionization detector (FID) was used. The column was HP 20M (carbowax20M) $(25 \mathrm{~m} \mathrm{X} 0.2 \mathrm{~mm}$ X $0.2 \mu \mathrm{m}$ film thickness). The column temperature was isothermal at $45^{\circ} \mathrm{C}$ for $3 \mathrm{~min}$. and then programmed to $220^{\circ} \mathrm{C}$ at a rate of $3^{\circ} \mathrm{C}$ $\mathrm{min}^{-1}$ for $50 \mathrm{~min}$. The temperature of the injection part was $200^{\circ} \mathrm{C}$ and that of the detector was $250^{\circ} \mathrm{C}$. The column head pressure was adjusted to $10 \mathrm{psi}$ and the relative concentration of the components were based on the peak areas obtained with a Shimadzu CR-18 Chromatopac. (Kirbaslar and Ismail Kirbaslar, 2004).

Statistical computer program was applied to calculate correlation coefficient and principal component analysis were also performed using the same program (SAS, 1996)

\section{RESULTS AND DISCUSSION}

The main constituents of the investigated petitgrain bigarade oils that stored at different temperature for 6 months are shown in Tables (1, 2 and 3). With respect to the petitgrain oil stored at room temperature (about $20^{\circ} \mathrm{C}$ ), its color that was yellow before storage become slightly brown yellow after 6 months of storage as seen in Table (1). On the other hand, the color of petitgrain oils stored at $4^{\circ} \mathrm{C}$ and $-18^{\circ} \mathrm{C}$ turned very slightly brown yellow and pale yellow after the same storage period (6 months), as seen in Tables ( 2 and 3 ). These findings were found to be agree with the opinion that the oil is quickly darkens and its odor deteriorates unless kept in wellsealed containers in a cool dark store place (Lota et al 2001).

Concerning the specific gravity and refractive index of the same investigated samples, the obtained data indicted a level of stability under any given storage temperature and storage time. On the other hand, optical rotation recorded a value of $+0.8^{\circ}$ at zero time and $+1^{\circ}$ for all petitgrain oil samples stored at the three different storage temperatures (Tables 1, 2 and 3 ).

Table 1. Some main constituents of Petitgrain bigarade oils produced in Egypt and stored for 6 months at room temperature (about $20^{\circ} \mathrm{C}$ )

\begin{tabular}{|lcccc|}
\hline Tested Parameters & \multicolumn{4}{c|}{ Storage periods / months } \\
\hline & zero & 1 & 3 & 6 \\
\hline Color (O.D) & Yellow & Yellow & Yellow & Very s.b.y* \\
& 0.561 & 0.555 & 0.597 & 0.764 \\
Specific gravity $\left(15^{\circ} \mathrm{C}\right)$ & 0.8853 & 0.8867 & 0.8841 & 08857 \\
Optical rotation $\left(20^{\circ} \mathrm{C}\right)$ & $+0.8^{\circ}$ & $+0.9^{\circ}$ & $+1^{\circ}$ & $+1^{\mathrm{o}}$ \\
Refractive index $\left(20^{\circ} \mathrm{C}\right)$ & 1.4652 & 1.4651 & 1.4655 & 1.4652
\end{tabular}

Arab Univ. J. Agric. Sci., 13(3), 2005 
Arab Univ. J. Agric. Sci., Ain Shams Univ., Cairo, 13(3), 795-805, 2005

\begin{tabular}{|lcccc|} 
& $1: 3$ & $1: 2.9$ & $1: 2.3$ & $1: 2.3$ \\
Solubility (v/v 70\% & more & more clear & Hazy & more hazy \\
alcohol) & clear & & & \\
Acid number & 0.50 & 0.90 & 1.10 & 1.20 \\
Ester number \% (as linaly & 43.90 & 44.10 & 46.6 & 41.30 \\
acetate) & & & & \\
\hline
\end{tabular}

* Very slightly brown yellow

Table 2. Main constituents of Petitgrain bigarade oils produced in Egypt and stored under cooling condition $4^{\circ} \mathrm{C}$ for 6 months.

\begin{tabular}{|lcccc|}
\hline \multicolumn{1}{|c}{ Tested Parameters } & \multicolumn{4}{c|}{ Storage periods $/$ months } \\
\hline & zero & 1 & 3 & 6 \\
\hline Color (O.D) & yellow & yellow & yellow & Very s.b.y.* \\
Specific gravity $\left(15^{\circ} \mathrm{C}\right)$ & 0.561 & 0.549 & 0.526 & 0.600 \\
Optical rotation $\left(20^{\circ} \mathrm{C}\right)$ & 0.8853 & 0.8866 & 0.8834 & 0.8866 \\
Refractive index $\left(20^{\circ} \mathrm{C}\right)$ & $+0.8^{\circ}$ & $+0.9^{\circ}$ & $+1^{\circ}$ & $+1^{\circ}$ \\
Solubility $\left(\mathrm{v} / \mathrm{v} 7 \%^{\circ}\right.$ & 1.4652 & 1.4650 & 1.4654 & 1.4652 \\
alcohol) & $1: 3$ & $1: 2.8$ & $1: 2.5$ & $1: 2.2$ \\
Acid number & more clear & more clear & more clear & more clear \\
Ester number $\%$ (as linaly & 43.90 & 43.05 & 46.6 & 1.20 \\
acetate) & & & & 42.7 \\
\hline
\end{tabular}

* Very slightly brown yellow

Table 3. Main constituents of Petitgrain bigarade oils produced in Egypt and stored under frozen condition $\left(-18^{\circ} \mathrm{C}\right)$ for 6 months

\begin{tabular}{|lcccc|}
\hline Tested Parameters & \multicolumn{4}{c|}{ Storage periods / months } \\
\hline & zero & 1 & 3 & 6 \\
\hline Color (O.D) & Yellow & Yellow & Yellow & Pale yellow \\
\hline
\end{tabular}

1- Food Science Department, Faculty of Agriculture, Ain Shams University, Shoubra El-Kheima, Cairo, Egypt.

(Received May 25, 2005)

(Accepted June 6, 2005) 
GC-Mass analysis of bitter orange petitgrain bigarade oil

\begin{tabular}{|lcccc|} 
Refractive index $\left(20^{\circ} \mathrm{C}\right)$ & 1.4652 & 1.4651 & 1.4645 & 1.4647 \\
Solubility (v/v 70\% alcohol) & $1: 3$ & $1: 2.6$ & $1: 2.7$ & $1: 2.3$ \\
& more clear & more clear & more clear & more clear \\
Acid number & 0.50 & 0.70 & 0.80 & 1.00 \\
Ester number \% (as linaly & & & & \\
acetate) & 43.90 & 44.90 & 46.90 & 41.20 \\
\hline
\end{tabular}


Arab Univ. J. Agric. Sci., Ain Shams Univ., Cairo, 13(3), 795-805, 2005

The available data indicate a relation between acid number and storage temperatures as given in Tables (1,2 and $3)$. For examples; acid number that was 0.50 at zero time increased to $1.20,1.20$ and 1.00 after 6 months of storage at $20^{\circ}$, $4^{\circ}$ and $-18^{\circ} \mathrm{C}$, respectively. However, ester number in terms of linalyl acetate showed upward and downward trends when the tested samples stored at $20^{\circ} \mathrm{C}$; values obtained were $43.90 \%$ at zero time and reached to $46.60 \%$ at the third month of storage and dropped to $41.30 \%$ when storage extend to 6 months. These results are matched with Dugo, (1994) who reported that the ester number of a similar oil sample was ranged from 25 to $68 \%$ and based on origin of the sample. On the other hand, solubility in $70 \%$ alcohol was greatly affected by storage condition where the solution was clear in both samples at zero time and those stored for 6 months under either cooling $\left(4^{\circ} \mathrm{C}\right)$ or frozen conditions $\left(-18^{\circ} \mathrm{C}\right)$. On contrary, samples stored at $20^{\circ} \mathrm{C}$ were found to be more hazy after 6 months storage

(Baaliouamer and Meklati, 1986).

The GC/MS chromatograms of bitter orange petitgrain oil produced in Egypt and stored at different temperatures namely fresh (zero time) as well as $20^{\circ} \mathrm{C}$, $4^{\circ} \mathrm{C}$ and $-18^{\circ} \mathrm{C}$ respectively are given in Fig. (1). The identified compounds of the analyzed samples are reported in Table (4). As can be seen from the same table and the figures, sixty-four components were identified, (representing over than $99.5 \%$ ) of the whole oil ; from which 31 components were highly and exactly well identified and confirmed according to the available standards.

From Table (4), it is clear that linalyl acetate, the percentage of which was never less than $25 \%$, is considered to be the major component of the ester fraction, followed by geranyl acetate $(4.2-5.6 \%)$ and citronellyl acetate $(0.054-0.073 \%)$. On the other hand, Linalool was the main alcohol, varying from $(30-33.7 \%)$, followed by $\alpha$-terpinol (2.5\%). Limonene, (E)- $\beta$-ocimene, myrcene and $\beta$-pinene were the main components among the monoterpene hydrocarbons, constituting 2.8 to $6.9 \%$ (Huang and $\mathbf{P u}, \mathbf{2 0 0 0}$ ).

Tricyclene, 6-methyl-5-hepten-2-one and p-mentha- $(2,4) 8$-diene have been identified in bitter orange petitgrain oil. Similar findings were given by Mosandl and Juchelka, (1997). Using Italian Citrus petitgrain oil.

Statistical analysis in terms of principle components (factor 1 and factor 2 ) is given in Table (5).Concerning "factor 1", data proved the suitability of storing the tested samples at about $20^{\circ} \mathrm{C}$ since the factor 1 is 0.9654 which is approximately going with that of the fresh sample that scored a value of 0.9672. On the other hand, when "factor 2 " was considered, values obtained namely 0.9844 and 0.9864 were noticed for samples stored at $4{ }^{\circ} \mathrm{C}$ and $-18{ }^{\circ} \mathrm{C}$, respectively. In other words; statistical analysis (principle component) confirmed the data given in Table (4) that indicates higher stability of the petitgrain bigarade oils during storage for 6 months at 4 or at $-18^{\circ} \mathrm{C}$. In terms of cost; it is

1- Food Science Department, Faculty of Agriculture, Ain Shams University, Shoubra El-Kheima, Cairo, Egypt. 
GC-Mass analysis of bitter orange petitgrain bigarade oil

recommended to store the tested samples at $4{ }^{\circ} \mathrm{C}$ since there is no significant changes between 4 and $-18{ }^{\circ} \mathrm{C}$ as indicated by analysis of variance given in the Table (5). This simply means that, properties of petitgrain bigarade oil stored at $4{ }^{\circ} \mathrm{C}$ for 6 months were too close to the un-stored sample (fresh sample).

Many components that identified in this oil were not previously detected. Moreover, results of the analyses of the 
Arab Univ. J. Agric. Sci., Ain Shams Univ., Cairo, 13(3), 795-805, 2005

1- Food Science Department, Faculty of Agriculture, Ain Shams University, Shoubra El-Kheima, Cairo, Egypt.

(Received May 25, 2005)

(Accepted June 6, 2005) 
GC-Mass analysis of bitter orange petitgrain bigarade oil

Arab Univ. J. Agric. Sci., 13(3), 2005 
10

Abd El-Rashid

Table 4. GC /MS analysis of bitter orange petitgrain bigarade oils obtained by. GC column HP-20M. (Values are given as area \%).

\begin{tabular}{|c|c|c|c|c|}
\hline \multirow[t]{2}{*}{ Identified components } & \multirow{2}{*}{ Zero time } & \multicolumn{3}{|c|}{ Storage under different temperature } \\
\hline & & $20^{\circ} \mathrm{C}$ & $4^{\circ} \mathrm{C}$ & $-18^{\circ} \mathrm{C}$ \\
\hline Tricyclene & 0.816 & 1.743 & 0.424 & 0.640 \\
\hline$\alpha$-Pinene & 0.172 & 0.157 & 0.175 & 0.145 \\
\hline$\beta$-Pinene & 0.984 & 0.871 & 0.973 & 0.963 \\
\hline Sabinene & 0.019 & 0.016 & 0.022 & 0.021 \\
\hline$\delta$-3-Carene & 2.013 & 1.822 & 2.029 & 2.020 \\
\hline Myrcene & 3.017 & 2.76 & 3.017 & 2.886 \\
\hline$\gamma$-Terpinene & 2.010 & 1.820 & 2.030 & 2.020 \\
\hline Limonene & 6.712 & 6.124 & 6.905 & 6.835 \\
\hline$\beta$-Phellandrene & 0.177 & 0.152 & 0.174 & 0.161 \\
\hline (Z)- $\beta$-Ocimene & 1.153 & 1.014 & 1.053 & 1.078 \\
\hline (E)- $\beta$-Ocinene & 3.078 & 2.771 & 2.832 & 2.899 \\
\hline Terpinolene & 0.750 & 0.670 & 0.658 & 0.692 \\
\hline 6-Methyl-5-hepten-2-one & 0.013 & 0.012 & Traces & Traces \\
\hline Nonanal & 0.173 & 0.150 & 0.171 & 0.170 \\
\hline P-cymenene & 0.050 & 0.027 & 0.038 & 0.042 \\
\hline Citronellal & 0.118 & 0.105 & 0.187 & 0.235 \\
\hline Linalool & 32.95 & 30.70 & 33.73 & 32.68 \\
\hline Linalyl acetate & 27.72 & 25.19 & 25.23 & 28.34 \\
\hline Trans- $\alpha$-bergamotene & 0.562 & 0.510 & 0.569 & 0.566 \\
\hline$(Z)-\beta$ - famesene & 0.283 & 0.264 & 0.293 & 0.274 \\
\hline Neral & 0.061 & 0.047 & 0.070 & 0.067 \\
\hline$\alpha$-humulene & 4.348 & 3.999 & 4.454 & 4.376 \\
\hline$\alpha$ - terpineol & 2.527 & 2.335 & 2.570 & 2.552 \\
\hline Bicyclogermacrene & Traces & Traces & Traces & Traces \\
\hline Geranyl acetate & 5.580 & 4.207 & 4.680 & 4.614 \\
\hline Nerol & 1.063 & 0.967 & 1.050 & 1.062 \\
\hline Geraniol & 2.273 & 2.111 & 2.292 & 2.258 \\
\hline (E)-nerolidol & 0.475 & 0.401 & 0.536 & 0.423 \\
\hline Citronellyl acetate & 0.073 & 0.055 & 0.054 & 0.054 \\
\hline P-cymene & 0.110 & 0.087 & 0.124 & 0.101 \\
\hline P-mentha-(2,4)-8-diene & 0.055 & 0.042 & 0.045 & 0.045 \\
\hline
\end{tabular}

Arab Univ. J. Agric. Sci., 13(3), 2005 
11

GC-Mass analysis of bitter orange petitgrain bigarade oil

Table 5. Principle components analysis of the identified constituents of petitgrain oil.

\begin{tabular}{|lcccc|}
\hline \multicolumn{1}{|c}{ Factor analysis } & \multicolumn{2}{c}{ principle components } & \multicolumn{2}{c|}{$\begin{array}{c}\text { Extraction of principle } \\
\text { components }\end{array}$} \\
\hline & Factor 1 & Factor 2 & From factor 1 & From factor 2 \\
\hline Zero time & 0.967219 & 0.153234 & 0.669415 & 0.958994 \\
Room temp. & 0.965461 & 0.152678 & 0.666678 & 0.955426 \\
Temp. $4{ }^{\circ} \mathrm{C}$ & 0.148811 & 0.984453 & 0.597539 & 0.991292 \\
Temp. $-18^{\circ} \mathrm{C}$ & 0.140673 & 0.986454 & 0.590345 & 0.992881 \\
Experimental Variance. & 2.099759 & 1.989550 & - & - \\
\hline
\end{tabular}

\begin{tabular}{|c|c|c|c|c|}
\hline Source & $\mathrm{DF}$ & SS & MS & $\mathbf{F}$ \\
\hline Factor & 3 & 1.2 & 0.4 & 0.999 \\
\hline Error & 124 & 6423.7 & 51.8 & \\
\hline \multirow[t]{2}{*}{ Total } & 127 & 6424.9 & & \\
\hline & & & & $\begin{array}{l}\text { Individual } 95 \% \text { CIs For Mean } \\
\text { Based on Pooled StDev }\end{array}$ \\
\hline Level & $\mathbf{N}$ & Mean & StDev & 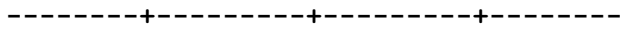 \\
\hline Zero & 32 & 3.103 & 7.372 & $(----------------*---------------)$ \\
\hline Room & 32 & 2.849 & 6.785 & $(--------------*----------------)$ \\
\hline $4^{\circ} \mathrm{C}$ & 32 & 3.027 & 7.215 & $(---------------\star *----------------)$ \\
\hline$-18^{\circ} \mathrm{C}$ & 32 & 3.070 & 7.402 & ( \\
\hline Pooled & ev $=$ & 7.197 & & 3.0 \\
\hline
\end{tabular}

four samples are in good agreement showing the robustness of the procedure used and the selection of raw material to be distilled. As a consequence, the results of this study can be thought as being representative of the composition of the Egyptian industrial bitter orange petitgrain oil.

\section{ACKNOWLEDGEMENTS}

This work was supported by the Sugar and Integrated Industries Company. The

authors thank the National Research Center for GC/MS analysis.

\section{REFERENCES}

AOAC. (1995). Official Methods of Analysis. $16^{\text {th }}$ Ed. Chapter 41, pp 41.1:

41.53. The Association of Official Analytical Chemists, Washington, DC, USA.

Baaliouamer, A., and B.Y. Meklati, (1986). Analysis of Bitter Orange Petitgrain Essential Oil by Combined 
Arab Univ. J. Agric. Sci., Ain Shams Univ., Cairo, 13(3), 795-805, 2005

CMS. Agric. Biol. Chem. 50(8): 21112114.

Boelens, M.H. (1991). Critical Review of the Chemical Composition of Citrus Oil. Perfum. Flav. 16(2): 17-34.

Boelens, M.H. and A. Oporto (1991). Natural Isolates From Seville Bitter Orange Tree. Perfum. Flav. 16(6): 1-7. Dugo, G. (1994). The Composition of the Volatile Fraction of the Italian Citrus Essential Oils, Perfum, Flav. 19(6): 2951. FCC. (1996). Food Chemical Codex. P. 342. National Academy of Sciences ( $3^{\text {rd }}$ Ed). Tawid Publications. Italy.

Huang, Y. and Z. Pu (2000). The chemical composition of the leaf essential oils from 110 citrus species, cultivars, hybrids and varieties of Chinese origin.

Perfum. Flav. 25(1): 53-66.

Kirbaslar, G. and S. Ismail Kirbaslar, (2004). Composition of Turkish bitter orange and lemon leaf oils. J. Essent. Oil Res., 16: 105-108.
Lawrence, B. (1993). Progress in Essential Oils. Perfum. Flav. 19(3):6169.

Lota, M.L.; D.R. Serra; C. Jacquemond; F. Tomi and $J$. Casanova, (2001). Chemical variability of peel and leaf essential oils of sour orange. Flav. Fragr. J. 16: 89-96.

Mondello L., and G. Dugo, (1996). Italian Citrus Petitgrain Oils. Part I. Composition of Bitter Orange Petitgrain oil. J. Essent. Oil Res, 8: 597-609. Mosandl, A., and D. Juchelka, (1997). Advances in the Authenticity Assessment of Citrus Oils. J. Essent. Oil Res., 9:512.

SAS, (1996). SAS / Stat User's Guide. Statistics. System for Windows, version 4.10 (release 6.12 TS level 0020,) SAS Inst., Inc.Cary. North Carolina, USA. Weiss, E.A. (1997). Essential Oil Crops. pp. 452-454. CAB International Wallingford. Oxon OX10 8DE. UK.

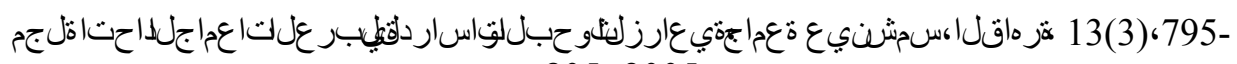 805، 2005

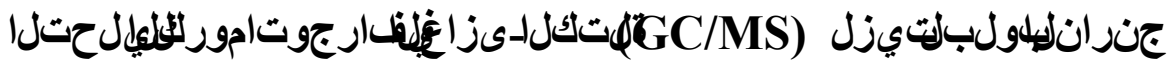

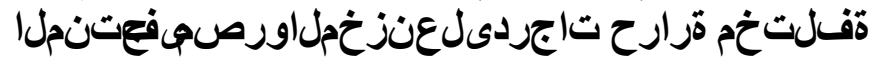

]52[

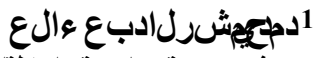

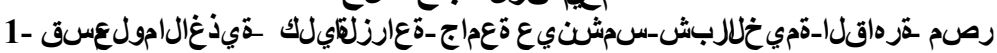

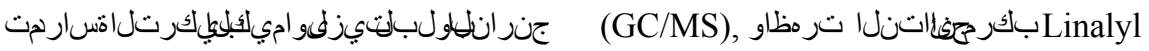

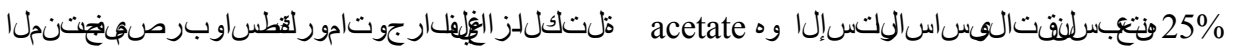

1- Food Science Department, Faculty of Agriculture, Ain Shams University, Shoubra El-Kheima, Cairo, Egypt.

(Received May 25, 2005)

(Accepted June 6, 2005) 
Arab Univ. J. Agric. Sci., Ain Shams Univ., Cairo, 13(3), 795-805, 2005

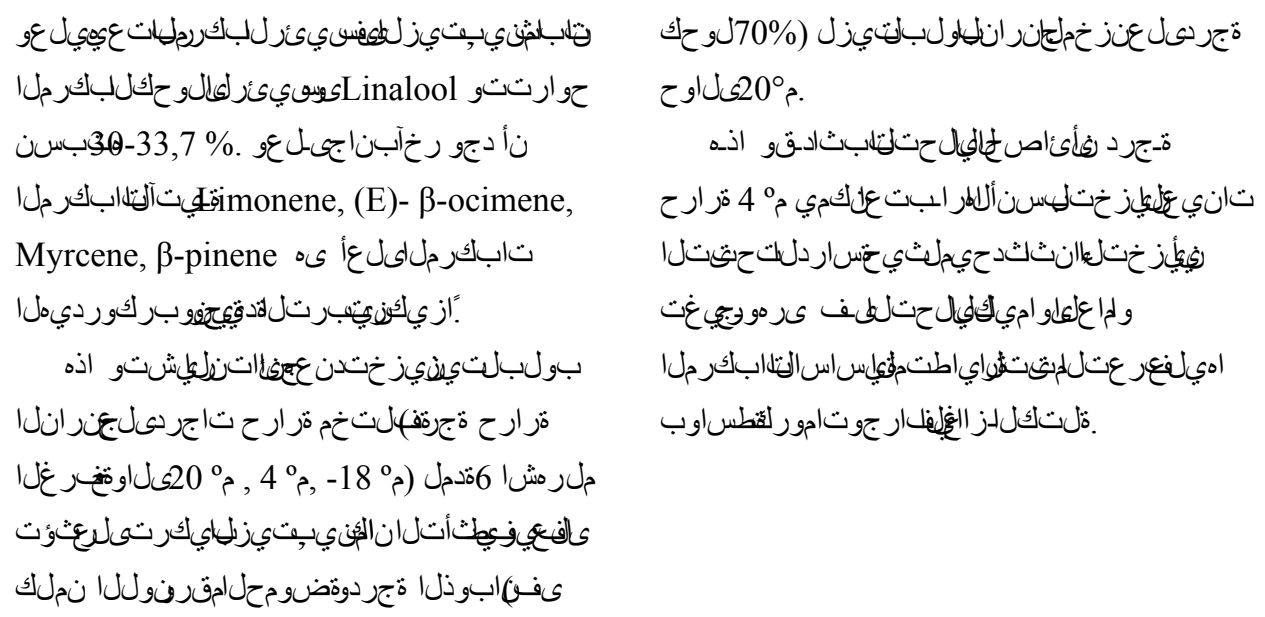

1- Food Science Department, Faculty of Agriculture, Ain Shams University, Shoubra El-Kheima, Cairo, Egypt. 